\title{
STRATEGI PENGEMBANGAN KAWASAN WISATA LIKUPANG KABUPATEN MINAHASA UTARA
}

\author{
Joppi Lengkong \\ Lucia C. Mandey \\ Charles R. Ngangi
}

\begin{abstract}
This study aims to evaluate the condition of tourist areas in Likupang, to know the internal factors and external factors Likupang tourist location development and its strategies of development. The type of this research is descriptive qualitative. Selection of sample research used purposive sampling method. The data collections in this research are primary and secondary data. Primary data were collected through interviews, observations and discussions and documentation. The interview was based on the questionnaire. The discussion was conducted by conducting Focus Group Discussion (FGD) Activities. While secondary data collected from various agencies, among others, Central Bureau of Statistics and North Minahasa District Office. Data were analyzed using SWOT analysis and Development Strategy. The result of research shows that the development strategy of Likupang tourism area based on SWOT analysis result lies in position of Quadrant I which is located between external opportunity and internal strength where the result of analysis obtained by total score of IFAS (Internal Strategic Factor Summary Analysis) is 3,498 and EFAS (External Strategic Factor Summary Analysis) is 3,854. The research concludes that Likupang tourism area development strategy can be done by maintaining panorama and sustainability of beach and Marine Park and also trying to complete infrastructure facilities especially the availability of electricity, water and internet network. Further accelerate the construction of new connecting road from the airport to Likupang so as to shorten the distance and travel time and also set up tourist information center for tourists.
\end{abstract}

Keywords: Strategy of Development, SWOT Analysis, Likupang Tourism Object, North Minahasa

\begin{abstract}
ABSTRAK
Penelitian ini bertujuan untuk mengevaluasi keadaan kawasan wisata di Likupang, mengetahui faktor internal dan faktor eksternal pengembangan lokasi wisata Likupang dan strategi pengembangannya. Jenis penelitian ini adalah deskriptif kualitatif. Pemilihan sampel penelitian menggunakan purposive sampling method. Data yang digunakan dalam penelitian ini berupa data primer dan sekunder. Data primer dikumpulkan melalui wawancara, observasi dan diskusi serta dokumentasi. Wawancara didasarkan pada kuesioner. Diskusi dilakukan dengan melaksanakan Kegiatan Focus Group Discussion (FGD). Sedangkan data sekunder dikumpulkan dari berbagai instansi antara lain Badan Pusat Statistik dan Kantor Kabupaten Minahasa Utara. Data dianalisa dengan menggunakan analisis SWOT dan Strategi Pengembangan. Hasil penelitian menunjukkan bahwa strategi pengembangan kawasan wisata Likupang berdasarkan hasil analisis SWOT, terletak pada posisi Kuadran I yang terletak antara peluang eksternal dan kekuatan internal dimana hasil analisis diperoleh nilai skor total IFAS (Internal Strategic Faktor Analisis Summary) adalah 3,498 dan EFAS (Eksternal Strategic Faktor Analisis Summary) adalah 3,854. Penelitian ini menyimpulkan bahwa strategi pengembangan kawasan wisata Likupang dapat dilakukan dengan tetap menjaga panorama dan kelestarian pantai dan taman laut serta berupaya untuk melengkapi sarana prasarana terutama ketersediaan fasilitas listrik, air dan jaringan internet. Selanjutnya mempercepat pembangunan jalan penghubung baru dari bandara ke Likupang sehingga mempersingkat jarak dan waktu tempuh serta mendirikan pusat informasi wisata bagi para wisatawan.
\end{abstract}

Kata kunci: Strategi Pengembangan, SWOT, Objek Wisata Likupang, Minahasa Utara 


\section{PENDAHULUAN}

\section{Latar Belakang}

Indonesia merupakan negara kepulauan yang kaya sumber daya alam, dimana sumber daya tersebut merupakan suatu potensi yang dapat dijadikan sebagai daya tarik wisata (Fandeli, 1995). Potensi wisata tersebut dapat berupa pemandangan alam taman, sungai, kebun binatang, arboterum, kampus, dan lainlain yang berada di desa ataupun kota. Potensi obyek alam ini tersebar mulai dari laut, pantai, dan pegunungan. Potensi kepariwisataan alam dalam suatu wilayah sering kali dimanfaatkan sebagai suatu aset yang mampu mendatangkan penghasilan yang cukup besar, membuka peluang usaha dan kerja serta tetap dapat berfungsi menjaga kelestarian alam (Fandeli, 1995).

Wilayah Indonesia sebagian besar merupakan kawasan perairan dengan berbagai keindahan alam pesisir, laut dan keanekaragaman hayati yang sangat potensial untuk dijadikan tempat tujuan wisata bagi wisatawan domestik maupun mancanegara. Berdasarkan PP No. 50 Tahun 2011 Tentang Rencana Induk Pembangunan Kepariwisataan Nasional, Pemerintah akan mengembangkan Destinasi Pariwisata Nasional (DPN), Kawasan Strategis Pariwisata Nasional (KSPN), serta Kawasan Pengembangan Pariwisata Nasional (KPPN). KPPN ini di antaranya juga termasuk KSPN dan tersebar di 50 DPN.

Pengembangan wisata alam merupakan salah satu pemanfaatan wisata yang dilakukan untuk membuat kawasan wisata tersebut menjadi lebih baik sehingga dapat menjadi daya tarik bagi para wisatawan. Pengembangan kawasan wisata ini di-maksudkan untuk menambah keindahan dari tempat wisata tanpa harus merusak ekosistem alam yang ada. Pengelolaan dan pemasaran yang baik adalah salah satu cara untuk mengembangkan kawasan wisata supaya dapat lebih dikenal oleh masyarakat. Sebagian besar kota-kota di Indonesia memanfaatkan dan mengembangkan sektor pariwisata alam sebagai daya tarik dan aset bagi pemasukan daerah (Nugrahaeni, 2013).

Dalam rangka pengembangan tujuan pariwisata, maka pembangunan pariwisata harus diarahkan pada pemanfaatan sumber daya alam, makin besar sumber daya alam yang dimiliki suatu Negara, maka semakin besar pula harapan untuk tujuan pembangunan dan pengembagan pariwisata. Tujuan pengembangan pariwisata akan berhasil dengan optimal apabila ditunjang oleh potensi daerah yang berupa obyek wisata, baik wisata alam maupun wisata buatan manusia (Yoeti, 1997;77). Pembangunan dan pengembangan daerah menjadi daerah tujuan daerah wisata tergantung dari daya tarik daerah itu sendiri yang dapat berupa keindahan alam, tempat bersejarah, tatacara hidup bermasyarakat, maupun upacara keagamaan. Sektor kepariwisataan perlu mendapat penanganan yang serius karena kepariwisataan adalah merupakan kegiatan lintas sektoral dan lintas wilayah yang saling terkait, di antaranya dengan sektor industri, perdagangan, pertanian, perhubungan, kebudayaan, sosial, ekonomi, politik, keamanan serta lingkungan. Pengembangan pariwisata tidak lepas dari faktor fisik dan non fisik (sosial, budaya, ekonomi), maka dari itu perlu diperhatikan unsur tersebut. Faktor geografi adalah faktor yang penting untuk pertimbangan perkembangan pariwisata. Perbedaan iklim merupakan salah satu faktor yang mampu menumbuhkan serta menimbulkan fariasi alam dan budaya, sehingga dalam mengembangkan kepariwisataan karakteristik fisik dan non fisik suatu wilayah perlu diketahui (Sujali, 2009).

Pengembangan pariwisata tanpa perencanaan yang baik akan banyak menemui hambatan atau kegagalan, terutama konflik yang terjadi antara pemerintah dan masyarakat (pengelola) karena adanya perbedaan visi dan misi pengembangan pariwisata itu sendiri. "Oleh karena itu mempersamakan pemahaman atau menyamakan persepsi merupakan jalan yang terbaik 
untuk mempertemukan tiga kepentingan dalam pengelolaan pariwisata (destinasi obyek wisata) yaitu pengunjung, pengelola (masyarakat) dan pemerintah" (Oka, 1997;21).

Pengembangan kawasan pariwisata di Kabupaten Minahasa Utara telah diupayakan berdasarkan letak geografis kawasan dan karakteristik serta kondisi dikawasan tersebut. Salah satu potensi wisata di Kabupaten Minahasa Utara yang menjadi obyek wisata andalan dan merupakan obyek wisata yang potensial untuk dikunjungi adalah kawasan obyek wisata Likupang, yang terdiri dari Likupang Timur, Likupang Barat dan Likupang Selatan. Berdasarkan data statistik jumlah pengunjung obyek wisata, obyek wisata Likupang merupakan obyek wisata yang selalu diminati oleh para wisatawan. Obyek wisata itu antara lain obyek wisata Pantai yang berada di Desa Pulisan, Desa Bahoi, Desa Lihaga, Desa Kinonang yang merupakan obyek wisata dengan latar belakang kondisi alam yang sangat indah dengan pemandangan laut yang begitu indah. Objek dan daya tarik wisata merupakan salah satu unsur penting dalam dunia kepariwisataan. Dimana objek dan daya tarik wisata dapat menyukseskan program pemerintah dalam melestarikan adat dan budaya bangsa sebagai asset yang dapat dijual kepada wisatawan. Objek dan daya tarik wisata dapat berupa alam, budaya, tata hidup dan sebagainya yang memiliki daya tarik dan nilai jual untuk dikunjungi ataupun dinikmati oleh wisatawan. Dalam arti luas, apa saja yang mempunyai daya tarik wisata atau menarik wisatawan dapat disebut sebagai objek dan daya tarik wisata.

Dalam rangka untuk pemeratakan perkembangan obyek wisata diperlukan sebuah kajian analisis untuk menggali dan menonjolkan potensi masing-masing obyek khususnya yang berada di Likupang, sehingga dapat disusun perencanaan yang menyeluruh untuk mengembangkan obyek wisata yang menarik, baik dalam hal pemaksimalan sumberdaya alam, penyediaan sarana prasarana wisata, serta wujud keterlibatan pemerintah daerah, swata, dan masyarakat lokal.
Berdasarkan uraian diatas, kegiatan kepariwisataan merupakan salah satu bidang usaha yang dipandang dapat memberikan manfaat dan keuntungan bagi masyarakat, pengusaha, maupun pemerintah dalam meningkatkan pendapatan asli daerahnya. Hal tersebutlah yang membuat penulis tertarik untuk menganalisis bagaimana strategi pengembangan kawasan wisata di Likupang Kabupaten Minahasa Utara ke dalam tesis yang berjudul: "Strategi Pengembangan Kawasan Wisata Likupang Kabupaten Minahasa Utara“.

\section{Rumusan Masalah}

Berdasarkan latar belakang di atas, rumusan masalah dalam penelitian ini ialah bagaimana strategi pengembangan kawasan wisata Likupang Kabupaten Minahasa Utara?

\section{Tujuan Penelitian}

Berdasarkan latar belakang masalah dan rumusan masalah yang telah diuraikan diatas, maka tujuan penelitian ini adalah :

1. Menganalisa faktor - faktor internal yang mendukung dan menghambat pengembangan pariwisata Likupang.

2. Menganalisa faktor - faktor eksternal yang mendukung dan menghambat pengembangan pariwisata Likupang.

3. Menganalisa strategi pengembangan kawasan wisata Likupang.

\section{Manfaat Penelitian}

\section{Manfaat Teoritis}

a. Menambah khasanah ilmu pengetahuan khususnya dalam bidang pengembangan pembangunan.

b. Dapat menambah literatur bahan kajian penelitian dalam pengembangan kawasan - kawasan wisata bagi peneliti-peneliti selanjutnya. 
2. Manfaat Praktis

a. Bagi peneliti: menambah wawasan tentang strategi pengembangan kawasan wisata secara khusus kawasan wisata di Likupang Kabupaten Minahasa Utara.

b. Dinas Pariwisata: sebagai bahan masukan kepada Pemerintah Kabupaten Minahasa Utara khususnya Dinas Pariwisata dalam mengembangkan kawasan wisata khususnya kawasan wisata di Likupang bekerjasama dengan pihak swasta dan diharapkan dapat membantu dalam merumuskan strategi kebijakan yang tepat dalam pengembangan kawasan wisata secara keseluruhan di Kabupaten Minahasa Utara.

\section{METODOLOGI PENELITIAN}

\section{Tempat dan Waktu Penelitian}

Lokasi penelitian dilakukan di wilayah Kecamatan Likupang Kabupaten Minahasa Utara. Penelitian dilaksanakan pada bulan Maret 2018 - Juni 2018.

\section{Jenis Data Penelitian}

Jenis data yang digunakan dalam penelitian ini adalah pendekatan deskriptif kualitatif dan kuantitatif dengan mengumpulkan data berupa data primer. Data primer dalam penelitian ini diperoleh secara langsung dari sumber terkait dengan penelitian mengenai keadaan obyek wisata di Likupang Kabupaten Minahasa Utara. Data diperoleh dari FGD (Focus Group Discussion) dan wawancara langsung dengan responden yang berupa pihak pengelola lokasi obyek wisata, tokoh masyarakat dan pelaku wisata yang mengetahui dengan jelas tentang kekuatan, kelemahan, peluang dan ancaman dari obyek wisata tersebut serta mengetahui latar belakang obyek wisata tersebut.

\section{Penentuan Sampel}

Teknik sampling yang digunakan adalah purposive sampling yaitu memilih responden di lokasi secara sengaja sesuai dengan kriteria penelitian. Kriteria yang dimaksud adalah responden yang diwawancarai merupakan wisatawan domestik maupun mancanegara di Kawasan Wisata Likupang Kabupaten Minahasa Utara dengan usia diatas 20 tahun dan bukan seorang pelajar yang dinilai dapat diajak berinteraksi sehingga mudah untuk mendapatkan data yang diperlukan dan dianggap sudah dapat menilai manfaat dari barang dan jasa sumber daya alam.

\section{Variabel Penelitian}

Variabel dalam penelitian ini terdiri dari:

1. Kawasan Wisata

Kawasan wisata yang dimaksud dalam penelitian ini adalah kawasan wisata yang berada di Likupang tepatnya di Likupang Barat, Likupang Timur dan Likupang selatan yang berada di Kabupaten Minahasa Utara.

2. Strategi Pengembangan

Pengembangan wisata di Likupang yang sebelumnya sudah ada aktivitas wisata yang bertujuan untuk meningkatkan potensi pariwisatanya serta hal-hal yang perlu dilakukan adalah merencanakan pengembangan wisata agar dapat lebih baik dari sebelumnya.

\section{Teknik Pengumpulan Data}

Penelitian ini menggunakan teknik pengumpulan data meliputi observasi, wawancara, FGD dan dokumentasi.

1. Teknik Observasi yaitu teknik pengumpulan data yang dilakukan dengan mengamati kondisi obyek wisata secara langsung dan membandingkan dengan obyek yang ada disekitarnya.

2. Teknik Wawancara (In-depth interview) yaitu dengan mewawancarai para pengelola obyek wisata untuk memperoleh informasi yang mendukung pengembangan pariwisata pada di Likupang Kabupaten Minahasa Utara. 
Selain itu, peneliti juga melihat kondisi masyarakat yang tinggal disekitar lokasi objek wisata di Likupang Kabupaten Minahasa Utara.

3. Teknik FGD (Focus Group Discussion) yaitu suatu bentuk penelitian kualitatif bagi sekelompok orang untuk mendiskusikan satu topik tertentu secara lebih mendalam dan terarah. Dimana peserta dengan bebas bertanya dan berbicara dengan anggota kelompok yang lain.

4. Teknik Dokumentasi yaitu sebagai bukti informasi selama peneliti melakukan penelitian berupa foto-foto, literature dokumen, surat kabar, dan referensi statistik.

\section{Teknik Analisis Data}

Teknik analisis data yang digunakan dalam penelitian ini adalah analisis SWOT (Strength, Weakness, Opportunities, Threat). Untuk merumuskan strategi pengembangan pariwisata pada obyek wisata Objek wisata dengan menggunakan analisis yang meliputi: tahap pertama, menggunakan analisis faktor strategi internal dan eksternal, setelah itu dilakukan riset SWOT matriks internal IFAS (Internal Strategic Faktor Analisis Summary) dan EFAS (Eksternal Strategic Faktor Analisis Summary), tahap berikutnya dari matriks IFAS dan EFAS ditentukan dengan uji analisis SWOT (Strength, Weakness, Opportunity, Threats).

Hal pertama yang harus dilakukan dalam penyusunan strategi dengan menggunakan alat analisis SWOT yaitu dengan menganalisis faktor internal dan eksternal suatu objek penelitian. Hal ini perlu dilakukan agar peneliti mengetahui dan memahami apa saja masalah yang ada dalam internal ataupun eksternal objek wisata.

Setelah selesai dilakukan analisis faktor internal dan eksternal, langkah selanjutnya yaitu melakukan riset SWOT. Riset SWOT bertujuan untuk menganalisis dan mengklasifikasikan secara kuantitatif faktor internal dan eksternal yang mempengaruhi bisnis suatu organisasi. Riset SWOT dilakukan dengan menggunakan perhitungan berdasarkan hasil FGD (Focus Group Discussion). Indrizal (2014) dalam jurnal yang berjudul Diskusi Kelompok Terarah menjelaskan bahwa FGD atau Focus Group Discussion merupakan suatu proses pengumpulan data dan informasi secara sistematis, terarah serta melibatkan beberapa peserta. Oleh karena itu, proses FGD yang melibatkan masyarakat setempat merupakan pendekatan yang paling sesuai.

Dalam menentukan analisis faktor strategi internal dan eksternal yaitu mengolah faktor-faktor strategis pada kondisi lingkungan internal dan eksternal dengan pemberian bobot dan rating pada setiap faktor strategis. Matrik Analisis SWOT merupakan identifikasi dari berbagai faktor yang menjadi landasan di dalam menyusun strategi pengembangan produk-produk wisata di suatu daerah. Melalui matriks SWOT dapat ditetapkan strategi pengembangan yang tepat. Matriks ini dapat menghasilkan empat sel kemungkinan alternative strategis.

Tabel 1. Model Matriks Analisis SwoT

\begin{tabular}{|c|c|c|c|}
\hline \multirow{7}{*}{$\frac{\frac{1}{2}}{\frac{1}{2}}$} & \multicolumn{3}{|c|}{ EKSTERNAL. } \\
\hline & \multirow{2}{*}{$\begin{array}{l}\text { Iderriflcation of } \\
\text { factor }\end{array}$} & Opportunities (O) & Treaths (T) \\
\hline & & Teatukan faktos peluang & Tentukan Faktos Ancaman \\
\hline & Strenght (S) & Svso & $S$ vi $\mathrm{T}$ \\
\hline & $\begin{array}{c}\text { Testukan faktor } \\
\text { kekuatan }\end{array}$ & $\begin{array}{c}\text { Strategi yang menpgunakan } \\
\text { kekuatin dan memanfaatkan } \\
\text { peluang }\end{array}$ & $\begin{array}{c}\text { Strateg yang } \\
\text { menggunakan kekuatan } \\
\text { dan mengatasi ancaman }\end{array}$ \\
\hline & Weakness (W) & W vw O & W ve T \\
\hline & $\begin{array}{c}\text { Tentukan faktor } \\
\text { kelemahan }\end{array}$ & $\begin{array}{c}\text { Strategi yang meminimalkan } \\
\text { kelemahan dan } \\
\text { memanfaatkan peluang }\end{array}$ & $\begin{array}{l}\text { Strategi meminimalkan } \\
\text { kejemahan dan } \\
\text { menghindari ancaman }\end{array}$ \\
\hline
\end{tabular}

Berdasarkan matriks SWOT di atas, dapat dijelaskan bahwa:

STRATEGI SO: Strategi ini dibuat berdasarkan jalan pikiran organisasi yaitu dengan memanfaatkan seluruh kekuatan untuk merebut dan memanfaatkan peluang yang ada.

STRATEGI ST: Strategi ini menggunakan kekuatan yang dimiliki organisasi untuk mengatasi ancaman. 
STRATEGI WO: Startegi ini diterapkan berdasarkan pemanfaatan peluang yang ada dengan cara meminimalkan kelemahan yang ada.

STRATEGI WT : Startegi ini didasarkan pada kegiatan yang bersifat defensive dan berusaha meminimalkan kelemahan yang ada serta menghindari ancaman.

\section{HASIL DAN PEMBAHASAN}

\section{Gambaran Umum Lokasi Penelitian}

Minahasa Utara adalah salah satu Kabupaten yang berada di Provinsi Sulawesi Utara, merupakan daerah otonom yang dimekarkan dari Kabupaten Minahasa melalui Undang-undang Nomor 33 Tahun 2003 dan diresmikan pada tanggal 7 Januari 2004. Kabupaten ini memiliki lokasi yang strategis karena berada di antara dua kota, yaitu Manado dan kota pelabuhan Bitung dengan batas-batas wilayah: sebelah utara berbatasan dengan Kabupaten Sangihe Talaud, Laut Sulawesi serta Laut Maluku, sebelah timur berbatasan dengan Kota Bitung, sebelah selatan berbatasan dengan Kabupaten Minahasa, dan sebelah barat berbatasan dengan Kota Manado. Luas Kabupaten Minahasa Utara adalah 1.059,24 km² dengan sebagian besar daerah yang memiliki topografi berbukit-bukit dan lereng, diantaranya terdapat Gunung Klabat (1.995 meter) yang merupakan gunung tertinggi di Provinsi Sulawesi Utara. Berdasarkan pembagian wilayah administratif, Kabupaten Minahasa Utara dibagi dalam 10 Kecamatan dan 131 desa/kelurahan dirinci 125 desa dan 6 kelurahan.

\section{Daya Tarik dan Potensi Wisata Kawasan Pengembangan Pariwisata Nasional Likupang}

Kawasan pengembangan pariwisata nasional Likupang memiliki daya tarik dan potensi pariwisata yang beragam, diantaranya daerah wisata bahari yang terdapat di atas maupun di bawah laut, wisata sejarah, dan wisata alam. Wisata bahari merupakan daya tarik wisata yang mendominasi hampir seluruh kawasan wisata Likupang. Daya tarik wisata ini paling banyak dikunjungi oleh wisatawan, baik wisatawan domestik maupun mancanegara. Keindahan pantai dan laut pada lokasi kawasan wisata Likupang dapat dinikmati melaui beberapa kegiatan seperti menyelam, berenang, menikmati keindahan panorama alam, water sport, serta aktifitas lainnya yang dapat dilakukan di pesisir pantai. Khusus untuk wisata selam, kawasan likupang memiliki kurang lebih 29 titik selam (divingspot) yang menjadi tempat penyelaman favorit di kawasan ini.

\section{Karakteristik Responden}

Responden penelitian berjumlah 30 orang dan memiliki karakteristik yang berbeda sehingga perlu dijelaskan melalui beberapa kategori yaitu jenis kelamin, usia, pendidikan dan pekerjaan responden.

1) Jenis Kelamin Responden

Jenis kelamin responden berdasarkan Tabel 2 menunjukkan bahwa responden berjenis kelamin laki - laki berjumlah 19 responden $(63,3 \%)$ sedangkan jenis kelamin perempuan sebesar 11 responden $(36,7 \%)$.

Tabel 2. Jenis Kelamin Responden

\begin{tabular}{clcr}
\hline No & $\begin{array}{l}\text { Jenis } \\
\text { Kelamin }\end{array}$ & Frekuensi & Persentase (\%) \\
\hline 1 & Laki-Laki & 19 & 63,3 \\
2 & Perempuan & 11 & 36,7 \\
\hline & Jumlah & 30 & 100 \\
\hline
\end{tabular}

Sumber: Hasil Analisis Data 2018

2) Usia Responden

Tabel 3 menunjukkan bahwa usia responden antara usia 20 sampai 30 tahun sebanyak 9 responden atau 30,0\% dan usia 31 sampai 40 tahun sebanyak 5 responden atau $16,7 \%$ sedangkan responden yang berumur lebih besar sama dengan usia 41 keatas sebanyak 16 responden atau $53,3 \%$. 
Tabel 3. Usia Responden

\begin{tabular}{rlcr}
\hline No & Usia & Frekuensi & Persentase (\%) \\
\hline 1 & $20-30$ & 9 & 30,0 \\
2 & $31-40$ & 5 & 16,7 \\
3 & $\geq 41$ & 16 & 53,3 \\
\hline \multicolumn{2}{r}{ Jumlah } & 30 & 100 \\
\hline
\end{tabular}

Sumber: Hasil Analisis Data 2018

\section{3) Pendidikan Responden}

Tabel 4 menunjukkan bahwa jumlah responden yang berpendidikan SMA/ SMK sederajat terdapat sebanyak 10 responden atau 33,3\% sedangkan $\mathrm{S} 1$ sebanyak 20 responden atau $66,7 \%$.

Tabel 4. Pendidikan Responden

\begin{tabular}{cccc}
\hline No & Pendidikan & Frekuensi & Persentase (\%) \\
\hline 1 & SMA/SMK & 10 & 33,3 \\
2 & S1 & 20 & 66,7 \\
\hline & Jumlah & 30 & 100 \\
\hline
\end{tabular}

Sumber: Hasil Analisis Data 2018

\section{4) Pekerjaan Responden}

Tabel 5 menunjukkan bahwa responden yang bekerja sebagai Aparatur sipil Negara (ASN) sebanyak 3 responden $(10,0 \%)$, swasta berjumlah 12 responden (40,0\%), wirausaha berjumlah 6 responden $(20,0 \%)$, swasta berjumlah 12 responden $(40,0 \%)$, mahasiswa/pelajar berjumlah 8 responden $(26,70 \%)$ dan jenis pekerjaan IRT berjumlah 1 responden $(3,3)$.

Tabel 5. Pekerjaan Responden

\begin{tabular}{llcr}
\hline No & Pekerjaan & Frekuensi & Persentase (\%) \\
\hline 1 & ASN & 3 & 10 \\
2 & Swasta & 12 & 40 \\
3 & Wirausaha & 6 & 20 \\
4 & Mahasiswa/Pelajar & 8 & 26,7 \\
5 & IRT & 1 & 3,3 \\
\hline & Jumlah & 30 & 100 \\
\hline
\end{tabular}

Sumber: Hasil Analisis Data 2018

\section{Hasil Analisis SWOT}

Hasil analisis faktor strategis internal menunjukkan bahwa skor total hasil analisis internal adalah 3,498 yang menandakan objek wisata di Likupang Minahasa Utara berada pada posisi "Kuat" dalam memanfaatkan kekuatan untuk menghadapi kelemahan yang dihadapi dalam pengembangan kawasan wisata di Likupang Minahasa Utara. Hal ini berarti bahwa pengembangan kawasan wisata di Likupang Minahasa Utara mampu mengatasi kelemahannya dalam memanfaatkan kekuatan yang dimiliki. Kekuatan utama dari pengembangan obyek wisata di Likupang terdapat pada faktor panorama objek wisata dan taman laut yang indah $(0,476)$ selanjutnya diikuti oleh lokasi wisata yang nyaman dan asri $(0,422)$ serta cocok untuk wisata keluarga $(0,403)$. Dengan demikian semakin banyak pilihan yang ditawarkan, semakin mempermudah wisatawan untuk menentukan pilihannya.

Kelemahan utama yang ada pada objek wisata di Likupang Minahasa Utara yaitu faktor sumber air dan listrik belum memadai $(0,158)$, kemudian diikuti secara berurutan faktor industri pendukung objek wisata berupa kerajinan tangan belum tersedia $(0,149)$ dan promosi/pemasaran objek wisata kurang sama dengan faktor kurangnya penjualan merchandise $(0,128)$. Setiap kawasan objek wisata selalu dicari terlebih dahulu sarana pendukung berupa ketersediaan air yang memadai, yang cukup serta adanya aliran listrik di lokasi wisata termasuk kawasan wisata di Likupang yang sudah dikenal banyak masyarakat. Selain itu, merchandise menjadi tujuan setelah berwisata dimana pada saat wisatawan pulang tentunya dengan adanya kerajinan tangan sebagai merchandise, membawa merchandise atau sebagai kenang - kenangan bagi sanak saudara, kenalan ataupun tetangga.

Hasil analisis faktor strategis eksternal melalui peluang dan ancaman mendapat skor total analisis eksternalnya adalah 3,854 yang menandakan bahwa pengembangan objek wisata di Likupang Minahasa Utara berada 
pada posisi eksternal "Kuat" dalam memanfaatkan peluang untuk mengatasi ancaman yang dihadapi. Hal ini berarti bahwa pengembangan objek wisata di Likupang Minahasa Utara direspon dengan baik terhadap peluang dan mampu mengatasi ancaman, sehingga dapat meminimalkan dampak dari ancaman yang mungkin timbul. Peluang utama dalam pengembangan objek wisata Di Likupang Minahasa Utara terdapat pada faktor tingginya minat masyarakat berpariwisata yang di dukung dengan skor sebesar 0,673 dan diikuti oleh faktor adanya pembangunan jalan penghubung dari airport ke Likupang dengan skor 0,663 dan Tersedianya jalur destinasi wisata internasional dengan skor 0,645 sedangkan faktor yang menjadi ancaman yaitu munculnya objek wisata lain yang lebih menarik, munculnya objek wisata lain yang lebih menarik dengan skor eksternal 0.366, selanjutnya diikuti oleh jarak tempuh rata - rata yang lebih dari 1 jam ke lokasi wisata dengan skor 0,185 selanjutnya diikuti oleh faktor kunjungan wisatawan dipengaruhi oleh informasi terror bom dan perkembangan paham radikal dengan skor 0,148 .

Hal tersebut memungkinkan terjadi karena adanya informasi - informasi yang diserap oleh masyarakat baik melalui media masa ataupun media cetak dan elektronik terlebih baik tempat wisata yang baru ataupun tentang teror bom yang terjadi di sejumlah daerah di Indonesia yang dapat menurunkan minat kunjungan wisatawan sebagai bentuk perlindungan diri dari keramaian.

Berdasarkan skor pembobotan total pada matriks internal-eksternal (IE) bahwa objek wisata Di Likupang Minahasa Utara berada pada sel I dengan skor 3,498 atau strategi melalui integrasi horizontal yang dapat digambarkan sebagai "tumbuh dan berkembang". Hal ini merupakan strategi utama untuk mengembangkan kawasan wisata Likupang dengan cara membangun dan memperluas kawasan wisata yang ada guna meningkatkan daya tarik wisatawan.

Hasil penghitungan analisis SWOT dapat ditentukan bahwa posisi relatif objek wisata Di Likupang berada pada titik koordinat $(0,04 ; 0)$ pada kuadran pertama yang menunjukkan bahwa objek wisata Di Likupang Minahasa Utara memiliki kekuatan dan peluang sehingga dapat memanfaatkan peluang yang ada dengan menggunakan kekuatan yang dimiliki. Strategi pengem-bangan yang sesuai dengan posisi objek wisata Di Likupang Minahasa Utara adalah strategi mendukung kebijakan pada pertumbuhan wisata.

Berdasarkan hasil analisis bahwa strategi pengembangan objek wisata Di Likupang Minahasa Utara terletak pada posisi kuadran I atau terletak antara peluang eksternal dan kekuatan internal (strategi pertumbuhan) yaitu strategi yang didesain untuk mencapai pertumbuhan jumlah kunjungan wisatawan (frekuensi kunjungan dan asal daerah wisatawan), aset (obyek dan daya tarik wisata, prasarana dan sarana pendukung), pendapatan (retribusi masuk dan jumlah yang dibelanjakan). Posisi kuadran I tersebut menunjukkan posisi yang sangat menguntungkan karena obyek wisata Di Likupang memiliki peluang dan kekuatan sehingga dapat memanfaatkan peluang yang ada. Strategi yang harus diterapkan dalam kondisi ini adalah strategi mendukung kebijakan pertumbuhan.

Selanjutnya menggunakan dengan matriks, memperlihatkan strategi-strategi yang dapat dilakukan untuk pengembangan obyek wisata Di Likupang. Strategi-strategi tersebut dimasukkan dalam Matriks Analisis SWOT. Matriks SWOT adalah matriks yang menginteraksikan faktor strategis internal dan eksternal. Matrik ini dapat menggambarkan secara jelas bagaimana peluang dan ancaman (eksternal) yang dihadapi dapat disesuaikan dengan kekuatan dan kelemahan yang dimiliki.

Berdasarkan hasil analisis Matriks SWOT (Tabel 6), dapat uraikan beberapa strategi dasar dalam rangka pengembangan obyek wisata Di Likupang Minahasa Utara sebagai berikut:

a. Menjaga keindahan panorama serta kenyamanan dan keasrian kawasan wisata didukung oleh kebijakan pemerintah terlebih berada di kawasan pengembangan pariwisata nasional (S1, S2, O4, O5). Strategi ini perlu dikembangkan, hal tersebut dikarenakan dengan adanya dukungan dalam bentuk kebijakan dari 
pemerintah kawasan wisata di Likupang dapat lebih ditingkatkan melalui pengaturan - pengaturan spot atau view dari kawasan wisata.

b. Meningkatkan informasi tentang jangkauan dan jarak tempuh terlebih untuk wisatawan mancanegara dengan adanya jalur destinasi wisata internasional (S6, O3). Salah satunya dengan membuat pusat informasi pariwisata di Likupang, wisatawan akan lebih cepat memperoleh informasi tentang tempat tujuan termasuk jarak tempuh yang dilalui untuk sampai ke kawasan wisata di Likupang.

c. Mengembangkan sarana wisata di sektor pariwisata dan melakukan promosi keindahan panorama yang berkesinambunan dan lingkungan yg bersih melalui teknologi yang ada (W1, W2, W3, W4, O2, O3, O4). Ketersediaan sarana prasarana yang mendukung diantaranya ketersediaan sumber air dan listrik. Salah satu cara mempromosikan objek wisata sebagai penunjang pengembangan yaitu memberikan pelatihan tentang keterampilan berbahasa asing terutama bahasa Inggris dan bahasa Mandarin bagi masyarakat sekitar kawasan wisata agar dapat menjadi pemandu wisata yang memiliki keahlian dalam berbahasa asing sesuai asal wisatawan mancara Negara terutama yang dari China yang nantinya meningkatkan pendapatan masyarakat.

d. Memaksimalkan penjualan souvenir melalui masyarakat sekitar untuk meningkatkan pendapatan (W6, W7, O4, O5). Pemberdayaan masyarakat melalui program - program pelatihan khususnya dalam bidang kerajinan tangan sehingga dapat menghasilkan karya yang nantinya dapat dijual kepada pengunjung atau wisatawan yang berkunjung. Kebanyakan wisatawan yang berkunjung ke suatu objek wisata selalu mencari souvenir sebagai kenang-kenangan yang mengingatkan bahwa pernah berkunjung ataupun sebagai bentuk hadiah bagi sudara yang berada di sekitar tempat tinggal mereka.
Dengan demikian pendapatan masyarakat di kawasan objek wisata akan semakin baik.

e. Penyediaan sumber air bersih dan listrik (W5, O4). Seluruh lokasi wisata membutuhkan ketersediaan air bersih dan listrik. Hal tersebut menjadi penunjang bagi wisatawan terlebih yang mandi di pantai yang membutuhkan air untuk membilas diri setelah bermain - main di pantai.

f. Berusaha memelihara dan menjaga alam sekitar serta melestarikan kawasan wisata Likupang serta menjaga solidaritas antar sesama (S1, T1, T2, T5). Strategi ini terkait dengan pemandangan alam yang indah dan sejuk yang ada di sekitar obyek kawasan wisata di Likupang, sehingga perlu di kembangkan terus melalui penghijauan dan reboisasi sesuai dengan kaidah konservasi yang ada agar lingkungan fisik sekitar tetap hijau yang menghasilkan udara sejuk serta pemandangan alam yang indah dan asri.

g. Menyediakan tourism information centre sebagai wadah informasi tentang kawasan wisata di Likupang (S1, S2, T4). Informasi yang jelas tentang kawasan wisata terlebih objek - objek wisata yang ada dapat ditampilkan pada pusat informasi pariwisata di Likupang yang nantinya mempermudah wisatawan mengenal lebih awal lokasi yang dituju serta dapat mengetahui terlebih dahulu tentang sarana - prasarana serta hal - hal pendukung yang ada pada objek wisata yang akan dituju.

h. Meningkatkan promosi dan fasilitas pendukungan (W1, W4, T1). Ketersediaan sarana yang memadai serta di informasikan kepada masyarakat luas akan membantu peningkatan kunjungan wisatawan pada objek wisata.

i. Menambah Atraksi wisata. (W1, (T2). Semakin banyak jenis atraksi yang disiaapkan oleh masing-masing objek wisata akan semakin memancing wisatawan berkunjung sehingga dengan 
peningkatan pengunjung akan semakin meningkat pula pendapatan pengelola objek wisata yang dapat membantu perluasan dan pengembangan objek wisata.

j. Menyediakan jalur wisata yang lebih baik (semakin dekat jarak tempuh, semakin baik) (W1, T4). Dengan adanya pembangunan jalan dari bandara menuju ke Likupang secara langsung akan lebih mempermudah akses menuju kawasan wisata di Likupang terlebih likupang berada pada kawasan pengembangan pariwisata nasional sehingga diharapkan percepatan pembangunan jalan penghubung dari airport ke Likupang.

Hasil uraian di atas menunjukkan bahwa obyek wisata berada pada posisi yang kuat dan berpeluang. Rekomendasi strategi yang diberikan adalah progresif, artinya obyek wisata di Likupang dalam kondisi prima dan mantap sehingga sangat dimungkinkan untuk terus melakukan perluasan, memperbesar pertumbuhan dan meraih kemajuan secara maksimal.

Panorama objek wisata dan taman laut di kawasan wisata secara internal memiliki kekuatan untuk menarik kunjungan wisatawan baik mancanegara maupun lokal. Selain itu lokasi wisata yang nyaman dan asri tentunya menjadi nilai tambah bagi objek wisata dalam menarik pengunjung. Kawasan wisata Likupang sendiri memang berada dalam kondisi yang aman sebagai lokasi wisata terlebih kawasan wisata di Likupang merupakan lokasi yang strategis serta dibantu dengan biaya masuk yang reltif murah dan didukung oleh keadaan jalan yang baik sehingga sangat membantu wisatawan untuk mencapai lokasi wisata terlebih yang berwisata bersama anggota keluarga. Dengan adanya kekuatan internal dari kawasan wisata Likupang bukan berarti tidak memiliki kelemahan. Kelemahan kelemahan tersebut muncul baik secara sadar ataupun tidak sadar oleh pengelolah kawasan wisata. Hal tersebut dapat dilihat dari kurangnya sarana prasarana seperti toilet umum yang tentunya tidak cukup apabila pengunjung meningkat. Proses promosi atau pemasaran objek wisata di Likupang masih kurang dikarenakan banyak sekali objek wisata yang ada tetapi sebagian besar masyarakat hanya mengetahui beberapa tempat saja sehingga pengembangan objek wisata tidak secara merata, terlebih dengan tidak tersedianya jaringan internet lebih mempersulit untuk mempromosikan secara langsung melalui jaringan internet. Seperti pengunjung dari luar negeri, kebanyakan berkunjung kesuatau tempat menginginkan untuk segera menga-upload hasil swafoto ke internet tetapi karena tidak tersedianya jaringan internet maka mereka harus ke lokasi yang memiliki jaringan internet. Selanjutnya kebersihan objek wisata tentunya merupakan suatu keharusan sebagai syarat peningkatan kunjungan wisatawan. Dengan kebersihan yang terjaga secara otomatis wisatawan disuguhkan pemandangan alam yang indah dan didukung dengan tidak adanya sampah yang berserakan yang mengganggu pandangan.

Secara eksternal, pada dasarnya obyek wisata di Likupang memiliki peluang dalam hal pengembangan dan pengelolaan untuk meningkatkan pengembangan kawasan wisata di Likupang. Dengan adanya kebijakan pemerintah daerah dan pusat yang berkomitmen untuk mengembangkan obyekobyek wisata di setiap daerah yang ada merupakan sebuah peluang bagi pengelola obyek wisata Di Likupang maupun pemerintah daerah Kabupaten Minahasa Utara untuk meningkatkan penghasilan serta pendapatannya. Minat masyarakat berpariwisata yang tinggi, adanya pembangunan jalan penghubung dari Airport Ke Likupang serta Likupang berada di kawasan pariwisata nasional tentunya sangat membantu pengelola kawaasan wisata. Semakin mudah akases menuju kawasan wisata maka semakin meningkat pengunjung ke kawasan itu serta majunya sebuah obyek wisata setidaknya membuka peluang lapangan kerja bagi masyarakat sekitar. 


\section{Tabel 6. Matriks SWOT}

\begin{tabular}{|c|c|c|}
\hline EFAS & $\begin{array}{l}\text { Kekuatan (Strength) } \\
\text { 1. Panorama objek wisata yang } \\
\text { indah } \\
\text { 2. Lokasi wisata yang nyaman dan } \\
\text { asri } \\
\text { 3. Aman sebagai lokasi wisata } \\
\text { 4. Lokasi yang strategis } \\
\text { 5. Biaya masuk relative murah } \\
\text { 6. Keadaan jalan yang baik } \\
\text { 7. Cocok untuk wisata keluarga }\end{array}$ & $\begin{array}{l}\text { Kelemahan (Weakness) } \\
\text { 1. Kurangnya sarana prasarana } \\
\text { 2. Promosi/pemasaran objek wisata } \\
\text { kurang } \\
\text { 3. Tidak tersedianya jaringan internet } \\
\text { 4. Sampah banyak berserakan } \\
\text { 5. Sumber air dan listrik belum memadai } \\
\text { 6. Kurangnya penjualan merchandise } \\
\text { 7. Industri pendukung objek wisata } \\
\text { berupa kerajinan tangan yang tidak } \\
\text { tersedia }\end{array}$ \\
\hline $\begin{array}{l}\text { Peluang (Opportunities) } \\
\text { 1. Adanya pembangunan jalan } \\
\text { penghubung dari Airport ke } \\
\text { Likupang } \\
\text { 2. Minat berpariwisata masya- } \\
\text { rakat yang tinggi } \\
\text { 3. Tersedianya jalur destinasi } \\
\text { wisata internasional } \\
\text { 4. Dukungan dari pemerintah. } \\
\text { 5. Likupang berada di kawasan } \\
\text { pengembangan pariwisata } \\
\text { nasional }\end{array}$ & $\begin{array}{l}\text { Strategi SO } \\
\text { 1. Menjaga keindahan panorama } \\
\text { serta kenyamanan dan keasrian } \\
\text { kawasan wisata didukung oleh } \\
\text { kebijakan pemerintah terlebih } \\
\text { berada di kawasan pengem- } \\
\text { bangan pariwisata nasional (S1, } \\
\text { S2,04,05) } \\
\text { 2. Meningkatkan informasi ten- } \\
\text { tang jangkauan dan jarak } \\
\text { tempuh terlebih untuk wisa- } \\
\text { tawan mancanegara dengan } \\
\text { adanya jalur destinasi wisata } \\
\text { internasional }(\mathrm{S} 6,03) \text {. }\end{array}$ & $\begin{array}{l}\text { Strategi W0 } \\
\text { 1. Mengembangkan sarana wisata di } \\
\text { sekto pariwisata dan melakukan } \\
\text { promosi keindahan panorama yang } \\
\text { berkesinambungan dan lingkunganyg } \\
\text { bersih melalui teknologi yang ada } \\
\text { (W1, W2, W3, W4, 02, 03, 04). } \\
\text { 2. Memaksimalkan penjualan souvenir } \\
\text { melalui masyarakat sekitar untuk } \\
\text { menigkatkan pendapatan (W6, W7, } \\
\text { O4, 05). } \\
\text { 3. Penyediaan sumber air bersih dan } \\
\text { listrik }(\mathrm{W} 5,04) \text {. }\end{array}$ \\
\hline $\begin{array}{l}\text { Ancaman(Threats) } \\
\text { 1. Kemungkinan longsor di- } \\
\text { sepanjang jalan menujulokasi } \\
\text { wisata } \\
\text { 2. Munculnya objek wisata lain } \\
\text { yang lebih menarik } \\
\text { 3. Gangguan keamanan pada } \\
\text { jalur menuju kawasan wisata } \\
\text { di Likupang } \\
\text { 4. Jarak tempuh rata- rata yang } \\
\text { lebih dari } 1 \text { jam ke lokasi } \\
\text { wisata } \\
\text { 5. Kunjungan wisatawan dipen- } \\
\text { garuhi oleh informasi terror } \\
\text { bom dan perkembangan } \\
\text { paham radikal }\end{array}$ & $\begin{array}{l}\text { Strategi ST } \\
\text { 1. Berusaha memelihara dan } \\
\text { menjaga alam sekitar serta } \\
\text { melestarikan kawasan wisata } \\
\text { Likupang serta menjaga } \\
\text { solidaritas antar sesama (S1, } \\
\text { T1, T2, T5) } \\
\text { 2. Menyediakan tourism infor- } \\
\text { mation centre sebagai wadah } \\
\text { informasi tentang kawasan } \\
\text { wisata di Likupang(S1, S2, T4) }\end{array}$ & $\begin{array}{l}\text { Strategi WT } \\
\text { 1. Meningkatkan promosi dan fasilitas } \\
\text { pendukungan (W1, W4, T1). } \\
\text { 2. Menambah Atraksi wisata. (W1,(T2) } \\
\text { 3. Menyediakan jalur wisata yang lebih } \\
\text { baik (semakin dekat jarak tempuh, } \\
\text { semakin baik) (W1, T4) }\end{array}$ \\
\hline
\end{tabular}

Sumber: Hasil Analisis SWOT 2018 
Meskipun demikian, terdapat beberapa hal yang perlu diantisipasi oleh pengelola obyek wisata maupun pemerintah daerah Kabupaten Minahasa Utara terhadap ancaman yang dapat mengganggu wisatawan dalam mengunjungi obyek wisata di Likupang. Beberapa hal yang menjadi ancaman bagi kawasan wisata di Likupang yaitu, lokasi menuju objek wisata terdapat beberapa tempat yang memiliki keadaan tanah yang miring kearah jalan akses dapat memungkinkan terjadinya longsor sehingga peran pemerintah dan pengelola kawasan wisata akan sangat membantu meningkatkan pengunjung dimana pengunjung merasa aman akan akses menuju kawasan wisata. Ancaman lainnya apabila muncul objek wisata lain yang berada di tempat lain dan dianggap lebih menarik dari kawasan wisata yang berada di Likupang. Oleh sebab itu strategi pengembangan kawasan wisata dibutuhkan sehingga meskipun muncul banyak objek wisata lain tetapi kualitas objek wisata di Likupang tetap menjadi primadona kunjungan objek wisata khususnya di Sulawesi Utara. Jarak tempuh juga menjadi ancaman namun hal yang paling mempengaruhi kunjungan yaitu adanya informasi melalui media tentang rangkaian aksi terror bom yang terjadi dibeberapa kota di Indonesia serta berkembangnya paham radikal yang semakin mempengaruhi kunjungan wisatawan dikarenakan wisatawan akan lebih memilih untuk menghindar dari tempat - tempat keramaian.

Kualitas menejemen atau pengelolaaan kawasan wisata yang semakin baik dengan memperhatikan kekuatan, kelemahan, peluang dan ancaman yang muncul dikawasan wisata Likupang akan sangat membantu meningkatkan daya Tarik wisatawan untuk berkunjung ke tempat tempat wisata yang berada di Likupang. Hal tersebut dikarena semakin baik pengembangan dan pengelolaan obyek wisata di Likupang dilaksanakan, semakin meningkat pula jumlah wisatawan yang datang mengunjungi obyek wisata di
Likupang. Dengan demikian objek wisata di Likupang akan semakin dikenal dan dengan kunjungan yang meningkat, membantu pendapatan pengelola kawasan wisata di Likupang yang secara otomatis membantu pengembangan selanjutnya menjadi lebih baik.

Pariwisata merupakan perjalanan dari satu tempat ke tempat lain, bersifat sementara, dilakukan secara perorangan maupun kelompok dengan tujuan untukmencari keseimbangan dan kebahagian dengan lingkungan hidup dalam dimensi sosial, budaya, alam, dan ilmu (Kodhyat dalam James J. Spillane, 1987). Menurut James J. Spillane (1987), pariwisata adalah perjalanan yang dilakukan dengan tujuan untuk mendapatkan kenikmatan, mencari kepuasan, mengetahui sesuatu, memperbaiki kesehatan, maupun untuk tujuan lainnya. Menurut Undang-undang Nomor 10 Tahun 2009 tentang kepariwisataan, yang dimaksud dengan wisata adalah kegiatan perjalanan yang dilakukan oleh seseorang atau sekelompok orang dengan mengunjungi tempat tertentu untuk tujuan rekreasi, pengembangan pribadi, atau mempelajari keunikan daya tarik wisata yang dikunjungi dalamjangka waktu sementara. Adapun pariwisata dideskripsikan sebagai kegiatan wisata dan didukung oleh berbagai fasilitas serta layanan yang disediakan oleh masyarakat, pengusaha, pemerintah, dan pemerintah daerah.

\section{KESIMPULAN DAN SARAN}

\section{Kesimpulan}

Berdasarkan hasil penelitian tentang strategi pengembangan kawasan wisata di Likupang di Kabupaten Minahasa Utara, peneliti dapat mengambil kesimpulan sebagai berikut:

1. Faktor-faktor internal yang mendukung pengembangan pariwisata Likupang adalah panorama objek wisata dan taman 
laut yang indah, lokasi pariwisata yang nyaman dan asri, aman sebagai lokasi wisata, biaya masuk yang relatif murah, keadaan jalan yang baik dan cocok untuk wisata keluarga. Sedangkan yang menjadi kelemahan pengembangan pariwisata Likupang adalah kurangnya sarana prasarana di kawasan wisata, promosi/ pemasaran objek wisata yang kurang, tidak tersedianya jaringan internet, sampah berserakan, sumber air dan listrik yang tidak tersedia, kurangnya penjualan merchandise serta industri pendukung objek wisata berupa kerajinan tangan belum tersedia.

2. Faktor-faktor eksternal yang mendukung pengembangan pariwisata Likupang adalah adanya pembangunan jalan penghubung baru dari airport ke Likupang, minat berpariwisata masyarakat yang tinggi, tersedianya jalur destinasi wisata internasional serta dukungan dari pemerintah dan Likupang berada di kawasan pengembangan pariwisata nasional. Sementara yang menghambat adalah kemungkinan terjadinya longsor disepanjang jalan menuju lokasi wisata, munculnya objek wisata lain yang lebih menarik, kurangnya minat pengunjung ke lokasi wisata di Likupang, jarak tempuh rata - rata yang lebih dari 1 jam ke lokasi wisata dan kunjungan wisatawan dipengaruhi oleh informasi teror bom dan perkembangan paham radikal.

3. Strategi prioritas berdasarkan SWOT adalah menjaga panorama dan kelestarian pantai serta taman laut serta melengkapi sarana prasarana terutama ketersediaan fasilitas listrik, air dan jaringan internet. Selanjutnya mempercepat pembangunan jalan peng-hubung baru dari bandara ke Likupang sehingga jarak tempuh menjadi lebih dekat dan menyiapkan pusat informasi wisata bagi para wisatawan.

\section{Saran}

Adapun saran dalam penelitian ini, sebagai berikut:

1. Pengunjung sangat berpengaruh terhadap kawasan wisata sehingga pengelola/ pemerintah harus memanjakan para pengunjung kawasan wisata, agar pengunjung tersebut merasa nyaman, aman dan kembali berkunjung. Kemudian dalam persaingan kawasan wisata, di Likupang harus lebih berinovasi dan mempertahankan serta melestarikan dan memperkenalkan budaya yang ada di Likupang khususnya dan Minahasa Utara umumnya sehingga menjadi nilai tambah bagi wisatawan dan para pesaingnya.

2. Dalam melaksanakan program - program yang dihasilkan, pemerintah perlu melakukan kerjasama dengan pihak swasta dan masyarakat, terutama untuk pendanaan dan pengelolaan lingkungan objek wisata serta mempermudah dalam pengurusan administrasi sebagai bentuk atau menarik investor lebih banyak.

3. Mempromosikan secara kontinue dengan even-even tahunan sedangkan promosi lewat media cetak dan elektronik dilakukan dengan membuat blog wisata di Likupang khususnya pada masing- masing objek wisata dan kerjasama dengan TV Nasional.

4. Memberikan penyuluhan atau pelatihan tentang basic life support (bantuan hidup dasar) agar pada saat terjadi kecelakaan seperti disebabkan oleh arus laut yang deras, masyarakat yang sudah mendapatkan pelatihan dapat memberikan tindakan dalam bentuk pertolongan pertama serta masyarakat lebih siaga ketika terjadi kecelakaan lainnya yang terjadi tiba-tiba. 


\section{DAFTAR PUSTAKA}

Badan Pusat Statistik. 2014. Sulawesi Utara Dalam Angka. Manado: BPS.

Fandeli, C. 1995. Dasar-Dasar Manajemen Kepariwisataan Alam. Yogyakarta: Penerbit Liberty.

Nugraheni D. 2013. Kajian Strategi Pengembangan Kawasan Wisata Pantai Suwuk Kabupaten Kebumen Ditinjau Dari Segi Pengelolaan Dan Pemasarannya. Jurnal Teknik PWK Volume 2 Nomor 1. Online: http:// ejournal-s1.undip.ac.id/ index.php/pwk. Hal 1.
Oka, Y. A. 1997. Perencanaan dan Pengembangan Pariwisata. Jakarta: Pradnya Paramita,). Hal. 21.

Peraturan Pemerintah No. 50 Tahun 2011 Tentang Rencana Induk Pembangunan kepariwisataan Nasional. Jakarta.

Sujali, 2009. Geografi Pariwisata dan Kepariwisataan, Diktat Kuliah, Fakultas. Geografi.

Yoeti, A. 1997. Pengembangan Pariwisata. Jakarta: Pradnya Paramita. Hal 77. 